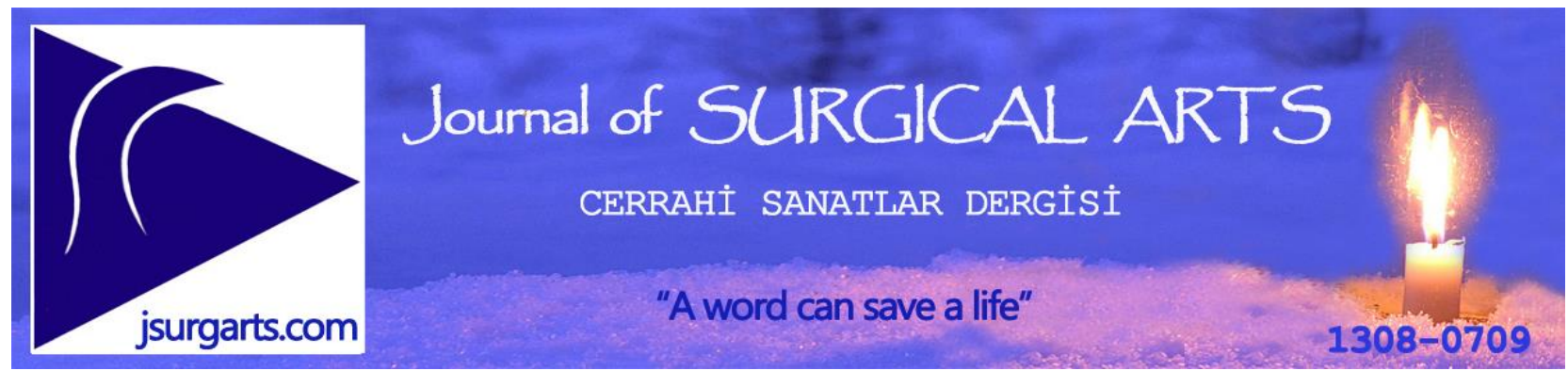

Clinical Practice Study

\title{
Surgical management of choledochal cysts in adults; Our experience
}

\section{Konjenital koledok kistlerinde cerrahi tedavi sonuçlarımız}

\author{
Mustafa Özsoy ${ }^{1}$, İbrahim Kılınç² \\ Y1ldırım Beyazıt University, Faculty of Medicine, Department of General Surgery ${ }^{1}$, Ankara, Turkey \\ Ankara City Hospital, Department of General Surgery ${ }^{2}$, Bilkent, Ankara, Turkey
}

Address: Dr. Mustafa Özsoy (https://orcid.org/0000-0002-7466-7743), dr.mustafaozsoy@gmail.com

How to cite: Özsoy M, Kılınç İ. Surgical management of choledochal cysts in adults; Our experience. J Surg Arts: 2021;14(1):11-16.

Received:12.12.2020

DOI: $\underline{\text { https://doi.org/10.14717/jsurgarts-210103 }}$

\author{
Accepted: 12.30 .2020
}

\section{ABSTRACT}

Choledochal cysts are the name given to the congenital cystic dilatation of the intrahepatic and/or extrahepatic bile ducts. It is most commonly observed in childhood ages but there are cases diagnosed in adulthood. They are precancerous lesions and should be resected when diagnosed. The aim of this study is to present the results of the patients who underwent surgical therapy due to choledochal cyst.

This study retrospectively included adult patients who were diagnosed with choledochal cyst between January 2015 and December 2019. In addition to demographic data such as age and gender, the operative and postoperative morbidity and mortality rates were documented.

The study included nine patients who underwent surgery due to a choledochal cyst. Of nine patients, three $(33 \%)$ were male and six $(66 \%)$ were female. The general mean age of the patients was 42.4 while the mean age of male patients was 56.5 and female patients was 35.5. The complaints were jaundice in three patients $(33 \%)$, acute pancreatitis in two patients $(22 \%)$, biliary colic abdominal pain in two patients $(22 \%)$, sepsis in one patient $(11 \%)$, and suspected malignity in one patient (11\%). Type 1 choledochal cyst was detected in all cases. In all patients included in the study, the external bile ducts including the intrapancreatic part were resected by incising the choledochal dilatation from the endpoint. The surgical procedure was performed laparoscopically in two cases $(22 \%)$. A biliary fistula that regressed with medical treatment was detected in postoperative one patient $(11 \%)$. A postoperative pancreas fistula was not detected in any patient. Margin positive adenocarcinoma was observed in the choledochal incisions of one patient who underwent laparoscopic surgery. The patient was taken to re-exploration and conventional pancreaticoduodenectomy was performed.

Choledochal cysts detected in older ages and male patients have a greater risk of malignity. Therefore, complete resection of bile ducts is necessary. The intraoperative frozen examination should be kept in mind as it protects patients from the second operation.

Keywords: Choledochal cyst; hepaticojejunostomy; cholangiocarcinoma; jaundice.

\section{ÖZET}

Koledok kistleri, safra yollarının intrahepatik ve/veya ekstrahepatik safra yollarının konjenital kistik dilatasyonuna verilen isimdir. En sık çocukluk yaş grubunda saptanmakla birlikte erişkin döneminde de tanı konulan vakalar bulunmaktadır. Prekanseröz lezyonlardır ve tanı konulduğunda rezeke edilmelidir. Bu makalemizde koledok kisti nedeniyle cerrahi tedavi uygulanan hastalarımızdaki sonuçlarımızı sunmayı amaçladık. 
Çalışmaya Ocak 2015 ile Aralık 2019 yılları arasında koledok kisti tanısı konulan erişkin yaş grubundaki hastalar retrospektif olarak dahil edilmiştir. Yaş, cinsiyet gibi demografik verilerinin yanı sıra operatif ve postoperatif morbidite ve mortalite oranları dokümante edildi.

Çalışmamıza koledok kisti tanısıyla cerrahi uygulanmış 9 hasta dahil edildi. 9 hastanın 3âü (\%33) erkek iken 6âsi (\%66) kadın cinsiyet idi. Hastaların genel yaş ortalaması 42,4 yıl iken erkeklerde ortalama yaş 56,6 yıl, kadınlarda ise 35,3 yıl olarak saptanmıştır. Başvuru şikÃøyeti $3(\% 33)$ hastada sarılık, 2 (\%22) hastada akut pankreatit, 2 (\%22) hastada biliyer kolik tarzda karın ağrısı, $1(\% 11)$ hasta sepsis ve $1(\% 11)$ hastada malignite şüphesidir. Olguların tümünde tip 1 koledok kisti saptanmıştır. Çalışmaya alınan tüm hastada koledok dilatasyonun bitiş yerinden kesilerek intrapankreatik kısmında dahil olduğu dış safra yolları rezeksiyonu uygulanmıştır. 2 olguda (\%22) cerrahi prosedür laparoskopik olarak uygulanmıştır. Postoperatif 1 (\%11) hastada medikal tedavi ile gerileyen safra fistülü saptandı. Postoperatif pankreas fistülü hiçbir hastada saptanmadı. Laparoskopik cerrahi uygulanan 1 hastada koledok kesitlerinde marjın pozitif adenokarsinom saptandı. Hasta re-eksplorasyona alınarak konvansiyonel pankreatikoduodenektomi uyguland1.

İleri yaş ve erkek hastada saptanan koledok kistleri yüksek malignite riski taşımaktadır. Bu nedenle safra yollarının komplet rezeksiyonu gereklidir. İntraoperatif frozen incelemesi hastaları ikinci ameliyattan korumasi nedeniyle akılda tutulmalıdır.

Anahtar kelimeler: Koledok kisti; hepatikojejunostomi; kolanjiokarsinom; sarılık

\section{INTRODUCTION}

Choledochal cysts are characterized by congenital cystic dilatation of the intrahepatic and/or extrahepatic bile ducts. Although it is common among Asian society, its incidence is low in Western populations. Two-third of the cases are of Asian origin (1). It is most commonly observed in childhood ages but there are cases diagnosed in adulthood. It is 3 to 4 times higher among the female sex compared to the male sex. The aim of this study is to present the results of the patients who underwent surgical therapy due to choledochal cyst.

\section{MATERIAL and METHOD}

Study Group

This study retrospectively included adult patients who were diagnosed with choledochal cyst between January 2015 and December 2019. In addition to demographic data such as age and gender, the operative and postoperative morbidity and mortality rates were documented (Table 1,2).

\section{Surgical Technique}

Anti-embolism stockings and under patient warmers were placed on patients on whom preoperative central venous catheter and epidural catheter were installed, for embolism prophylaxis. The operation started after cleaning the surgery area. All surgical procedures were performed by a surgeon who was experienced in hepatobiliary surgery. The operations were started with mini-laparotomy. Inverted $\mathrm{L}$ incision was used in patients on whom pathology was not detected in the general exploration of the abdomen. Hepatogastric ligament was opened after placing the Thompson ecarteurs. Duodenum and pancreatic head were mobilized with the partial Kocher maneuver. Then, the right, left and main hepatic artery are slanged by dissecting the hepatoduodenal ligament. The choledoch is turned over the junction of the cystic canal and incised at the endpo- int of the cyst. The portal vein is slanged for safety. Choledoch is dissected until the pancreaticobiliary junction including the intrapancreatic part (Figure 1, 2 ). The bleeding that develops during this procedure is controlled with bipolar or sutures. After the complete resection of the choledochal cyst, bilioenteric continuity is maintained with Roux en-Y hepaticojejunostomy (Figure 3).

\begin{tabular}{|c|c|c|}
\hline \multicolumn{3}{|c|}{$\begin{array}{l}\text { Table 1: Demographic and preoperative } \\
\text { findings. }\end{array}$} \\
\hline \multicolumn{2}{|c|}{ Parameters } & Number \\
\hline \multirow[t]{2}{*}{ Gender } & Male & $3(\% 33)$ \\
\hline & Female & $6(\% 66)$ \\
\hline \multirow[t]{2}{*}{ Age } & Male & 56,6 \\
\hline & Female & 35,3 \\
\hline \multirow{5}{*}{$\begin{array}{l}\text { Co- } \\
\text { morbidity }\end{array}$} & None & $5(\% 55)$ \\
\hline & Diabetes & $1(\% 11)$ \\
\hline & COPD & $1(\% 11)$ \\
\hline & Chronic hepatitis & $1(\% 11)$ \\
\hline & Hypertension & $1(\% 11))$ \\
\hline \multirow{5}{*}{ Clinic } & Jaundice & $3(\% 33)$ \\
\hline & Acute pancreatitis & $2(\% 22)$ \\
\hline & Stomachache & $2(\% 22)$ \\
\hline & Cholangitis/Sepsis & $1(\% 11)$ \\
\hline & Malignancy & $1(\% 11)$ \\
\hline \multirow{2}{*}{$\begin{array}{l}\text { Total bili- } \\
\text { rubin }\end{array}$} & Male & $10 \mathrm{mg} / \mathrm{dL}$ \\
\hline & Female & $\begin{array}{c}5,15 \\
\mathrm{mg} / \mathrm{dL}\end{array}$ \\
\hline \multirow[t]{2}{*}{ Ca 19-9 } & Male & $690 \mathrm{U} / \mathrm{mL}$ \\
\hline & Female & $276 \mathrm{U} / \mathrm{mL}$ \\
\hline \multirow{2}{*}{$\begin{array}{l}\text { ERCP \& } \\
\text { stent }\end{array}$} & Male & $3(\% 100)$ \\
\hline & Female & $2(\% 33)$ \\
\hline
\end{tabular}




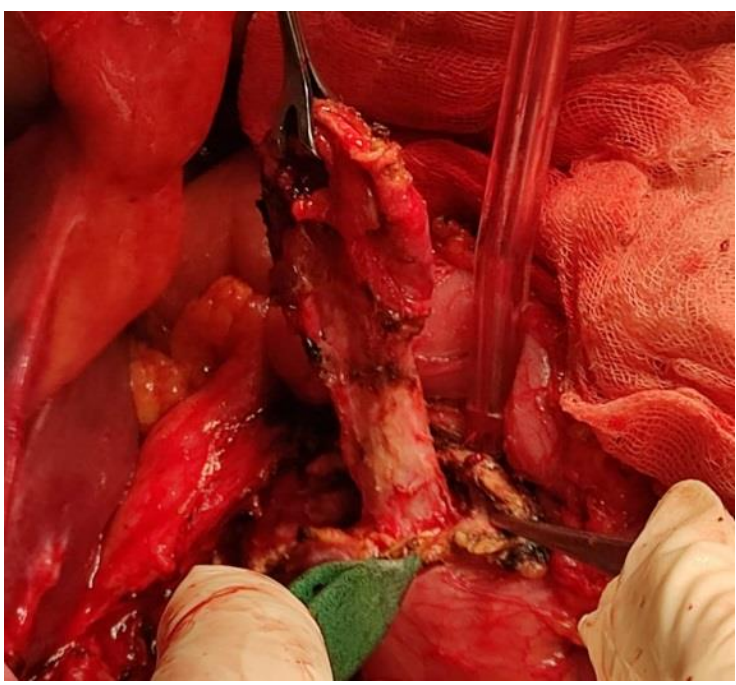

Figure 1: Dissection of the intrapancreatic biliary tree after the transection of choledoch.

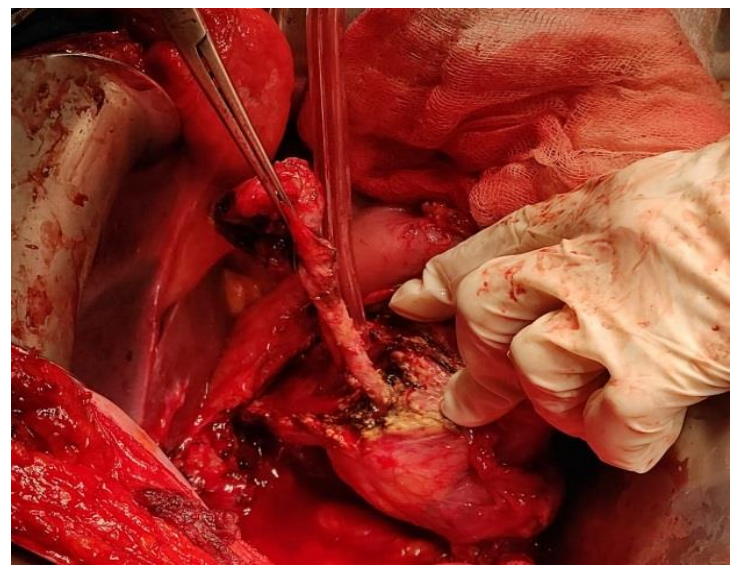

Figure 2: Intraoperative image after the dissection of choledochal cyst until the pancreaticobiliary junction.

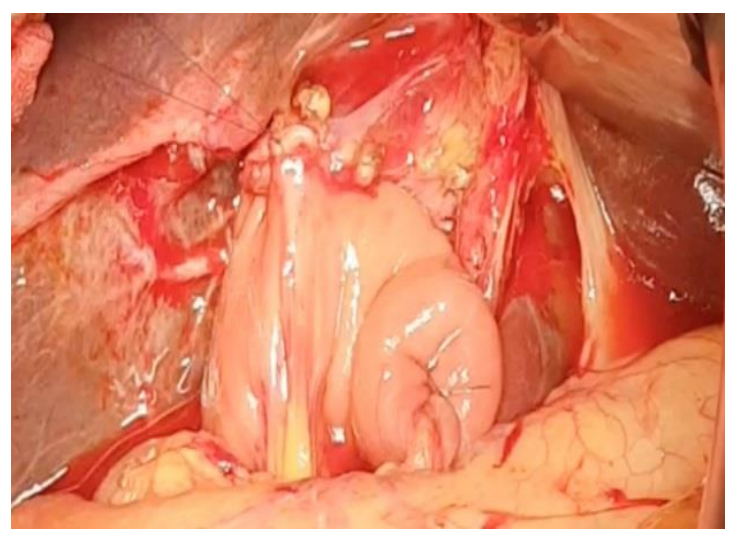

Figure 3: Intraoperative image of maintaining the bilioenteric continuity with Roux-en-Y hepaticojejunostomy after the choledochal cyst resection.

\section{Postoperative Follow-Up}

All patients were monitored in the intensive care after the surgery. Early mobilization and clexa- ne 4000 anti-Xa / $0.4 \mathrm{ml}$ treatment at the postoperative sixth hour were started for deep venous embolism prophylaxis. Clexane treatment was continued until the seventh day and then, aspirin was used for maintenance. Nasogastric drainage was removed on the first postoperative day, and oral water was started. If the bilirubin values in the samples sent from the drains were three times lower than the blood bilirubin value on the postoperative third day, then the drains were removed. All patients whose oral feeding was increased in line with their tolerance were exterminated when no surgical morbidity was observed.

\section{Postoperative complication}

If the drain bilirubin value was three times higher than the blood value, then the diagnosis of the biliary fistula was made. The diagnosis of sepsis was made in line with the increasing fever, clinical picture, and acute phase reactant. Possible malignancy screening was performed in line with the histopathological examination of the surgical pieces. The mortality and morbidity rates were documented within the first postoperative month (Table 2).

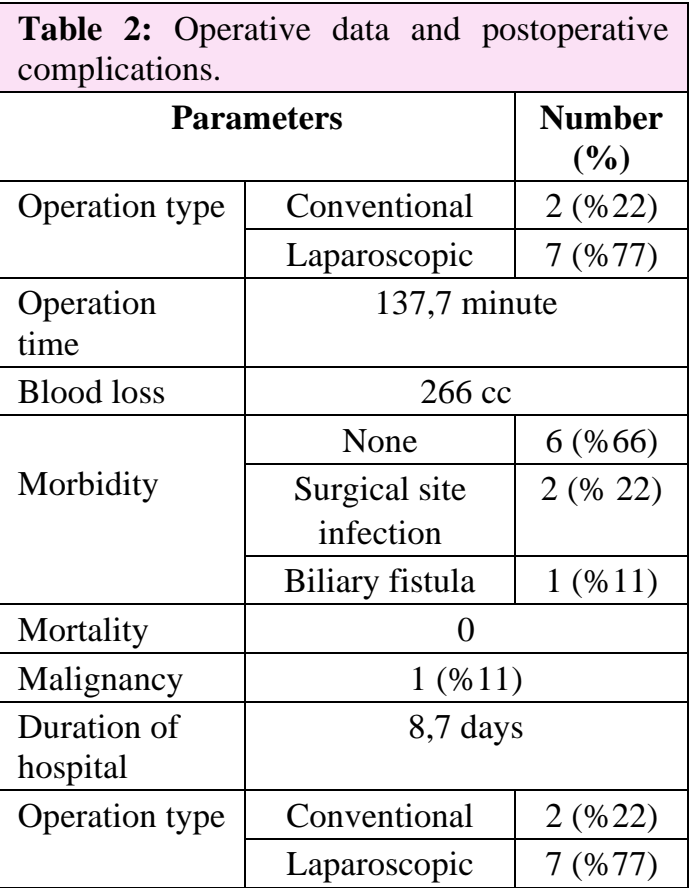

\section{RESULTS}

This study included nine patients who underwent surgery due to the diagnosis of choledochal cyst between January 2015 and December 2019. Of nine patients, three $(33 \%)$ were male and six $(66 \%)$ were female. The general mean age of the patients was 42.4 while the mean age of male patients was 56.5 and female patients was 35.5 . Five $(55 \%)$ patients did not have any comorbid diseases. Triphasic abdominal tomography (CT) was performed in all patients to reveal vascular anatomy while magnetic resonance cholangiopancreatography (MRCP) was 
performed in all patients to determine the limits of biliary tract dilatation in the preoperative period (Figure 4). The complaints were jaundice in three patients $(33 \%)$, acute pancreatitis in two patients (22\%), biliary colic abdominal pain in two patients $(22 \%)$, sepsis in one patient $(11 \%)$, and suspected malignity in one patient $(11 \%)$. It was detected that two patients $(22 \%)$ underwent cholecystectomy and three patients $(33 \%)$ had cholelithiasis.

The average of the total bilirubin values of the patients during the admission was found as 6.7 $\mathrm{mg} / \mathrm{dl}$. The general average of Ca19-9 during diagnosis was determined to be $414 \mathrm{U} / \mathrm{ml}$. Preoperative endoscopic retrograde cholangiopancreatography (ERCP) stenting was performed in five patients $(55.5 \%)$ with cholangitis. The average choledoch diameter was detected as $67.2 \mathrm{~mm}$ based on the ERCP, MRCP, and intraoperative findings. Type 1 choledochal cyst was detected in all cases. In all patients included in the study, the external bile ducts including the intrapancreatic part were resected by incising the choledochal dilatation from the endpoint over the cystic canal junction.

Reconstruction was performed with Rouxen-Y hepaticojejunostomy, and the surgical procedure was performed laparoscopically in two cases $(22 \%)$. The conventional method was preferred for the remaining seven cases $(77 \%)$. The mean operation duration was $137.7 \mathrm{~min}$ and the mean blood loss was $266 \mathrm{cc}$. Reproduction was detected in eight $(88 \%)$ of the bile samples taken before the intraoperative bile duct transection. The most commonly detected microorganism was Escherichia coli. A biliary fistula that regressed with medical treatment was detected in postoperative one patient $(11 \%)$. A postoperative pancreas fistula was not detected in any patient. While there was no mortality, postoperative morbidity was observed in three patients (33\%).

The average hospital stay was 8.7 days. Margin positive adenocarcinoma was observed in the choledochal incisions of one patient who underwent laparoscopic surgery in the histopathological examination of the surgery material. The patient was taken to re-exploration and conventional pancreaticoduodenectomy was performed. The patients who did not have surgical problems on the 10th postoperative day were discharged.

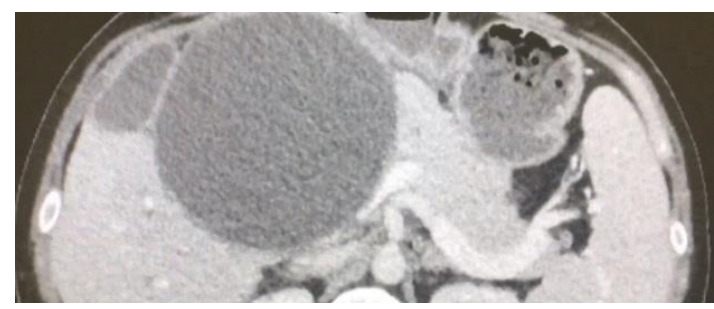

Figure 4: BT Image of the giant choledochal cyst.

\section{DISCUSSION}

Congenital cystic dilation of bile ducts is divided into five types by Todani based on the location and shape of the involvement in the biliary tree (3) (Figure 5). Type 1 choledochal cysts, which are named as the fusiform dilation of extrahepatic bile ducts, are the most common group among these types with a ratio of $67.7 \%$ (4). Choledochal cysts are often asymptomatic in the adult age group and it is diagnosed incidentally in imaging tests performed for other reasons. Other application complaints are abdominal pain, vomiting, cholelithiasis, cholangitis, pancreatitis, and malignancy. While computed tomography reveals the relationship of choledochal cysts with vascular structures and neighboring organs better, the degree of involvement in the bile ducts can best be achieved with magnetic resonance imaging. While the male sex is dominant in this study, the patients were diagnosed with a choledochal cyst in line with the tests made due to symptomatic complaints, unlike the literature. All patients had jaundice, and the average choledoch diameter was $67 \mathrm{~mm}$, Ca 19-9 level was $414 \mathrm{U} / \mathrm{ml}$. Preoperative biliary drainage was performed with ERCP on five patients with cholangitis in addition to computed tomography and MRCP imaging in the preoperative period. Type 1 choledochal cyst was detected in all cases.

Choledochal cysts, which are quite rare, are precancerous lesions and have the risk of cholangiocarcinoma development at the rate of $10 \%$ if not treated (5). The supposed surgical therapy option for choledochal cysts was the biliary diversion in the form of choledocoenterostomy before detecting the malignancy development risk. The biliary diversion operation is contraindicated due to the risk of malignancy in the remaining bile ducts $(6,7)$. Patients who underwent only biliary diversion encounter four-times increased malignity risk compared to patients who underwent resection. The malignity risk continues even after partial resection of the cyst. The prevalence of malignity after the partial resection was reported to be $7.3 \%(8,9)$. Today's accepted surgical therapy method is the complete resection of bile ducts where the cyst is completely removed, and Roux-en-Y hepaticojejunostomy (10). Therefore, the patients who previously underwent biliary drainage or partial cyst resection due to choledochal cysts need re-operation and complete resection of cysts. The complication rates, in particular biliary and pancreas fistula, after the complete resection of bile ducts change between 15-20\% (10, 11). Considering that the five-year survival rate is $5 \%$ in the case of cholangiocarcinoma development, the accepted complication rates for cyst resections should be actualized (12). 


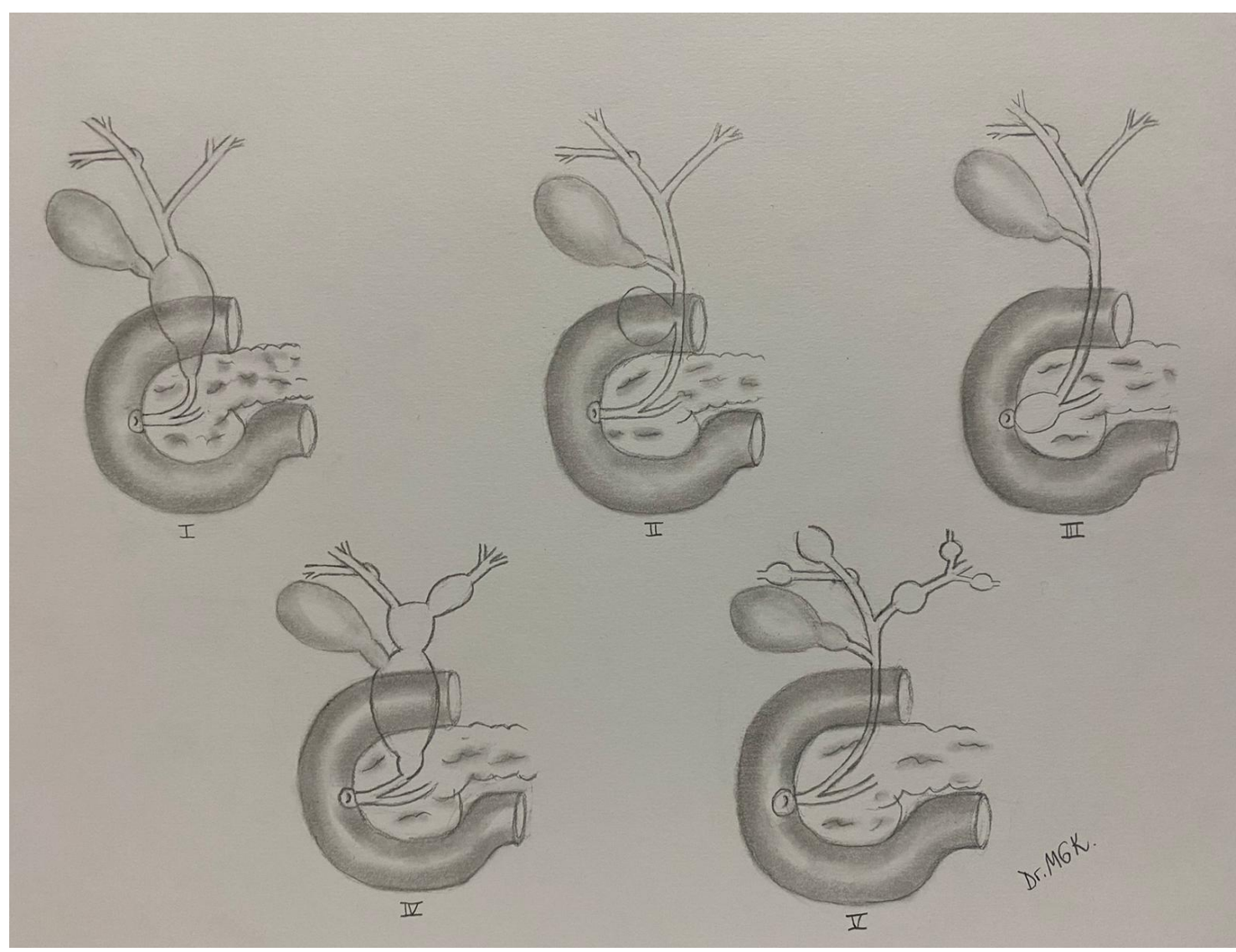

Figure 5: Todani classification for congenital cystic dilation of bile ducts.

Chronic pancreatic and biliary reflux secondary to abnormal pancreaticobiliary duct junction is considered responsible for the development of malignity (13). It was found that genetic predisposition, family history, and epithelial abnormalities play a role in the pathogenesis of the malign degeneration of choledochal cysts. Inflammation secondary to low-grade chronic cholangitis causes dysplasia, metaplasia, and carcinogenesis in the epithelium (14). While the conventional method was preferred for seven patients, the laparoscopic approach was used for two patients. While pancreas fistula was not detected on any patient, one patient was detected to have biliary fistula regressed with medical treatment. The morbidity rate was $33 \%$ in this study. After the detection of cholangiocarcinoma in the histopathological examination of the postoperative surgical piece of one patient who underwent laparoscopic intervention, pancreaticoduodenectomy was performed. The study has a quite limited and low number of patients. Therefore, the percentage values of the study are relatively higher compared to the literature. Additionally, it was found that intraoperative frozen examination might protect the patient from additional morbidity if surgery will be performed on male and elderly patients due to choledochal cyst.

There are differences between the types of choledochal cyst types and malignity development risks. Type 1 and type 4 have a significantly higher risk of malignity compared to Type 2 and Type 3 . There is a consensus that the main reason for this difference is the pancrecobiliary canal junction abnormality in Type 1 and Type 4. Type 2 and Type 3 does not contain this canal abnormality. Age is an important factor in the malignity development of choledochal cysts. The risk of malignity increases in parallel with age (15). Nicholl et al. found that the cancer incidence of those aged below 30 is close to zero while this rate is higher than $50 \%$ among those aged older than 51 (16). Home et al. determined that the cancer incidence peaked between the ages of 61 and 70. The average of cholangiocarcinoma development in choledochal cysts is 49.5 while the mean age for cancer development in cholangiocarcinoma is 65. The age of cholangiocarcinoma development in choledochal cysts is 20 years earlier compared to the general population (17).

In conclusion, choledochal cysts detected in older ages and male patients have a greater risk of malignity. Therefore, complete resection of bile ducts is necessary. In addition to sufficient imaging methods in the preoperative period, the intraoperative frozen examination should be kept in mind to protect patients from a second operation.

Conflict of interest: No conflict of interest was declared by the authors. 


\section{REFERENCES}

1. Liu Y, Yao X, Li S, et al. Comparison of therapeutic effects of laparoscopic and open operation for congenital choledochal cysts in adults. Gastroenterol Res Pract 2014;2014:670260.

2. O'Neill JA, Jr. Choledochal cyst. Curr Probl Surg 1992;29:361-410.

3. Todani T, Watanabe Y, Narusue M, et al. Congenital bile duct cysts: classification, operative procedures, and review of thirty- seven cases including cancer arising from choledochal cyst. Am J Surg 1977;134:263-9.

4. She WH, Chung HY, Lan LC, et al. Management of choledochal cyst: 30 years of experience and results in a single center. J Pediatr Surg 2009;44: 2307-11.

5. Soares KC, Kim Y, Spolverato G, et al., Presentation and clinical outcomes of 'choledochal cysts in children and adults: a multi-institutional analysis, JAMA Surg. 2015;150:577-84.

6. Jordan PH, Goss JA, Rosenberg WR, Woods KL. Some considerations for management of choledochal cysts. Am J Surg 2004;187:790-5.

7. Lenriot JP, Gigot JF, Ségol P, Fagniez PL, Fingerhut A, Adloff M. Bile duct cysts in adults: a multi-institutional retrospective study. French Association for Surgical Research. Ann Surg 1998;228: 159-66.

8. Komi N,Tamura T,Tsuge S, Miyoshi Y, Udaka H, Takehara H. Relation of patient age to premalignant alterations in choledochal cyst epithelium: histochemical and immunohistochemical studies. J Pediatr Surg 1986;21:430-3.

9. Nagata E, Sakai K, Kinoshita H, Hirohashi K. Choledochal cyst: complications of anomalous connection between the choledochus and pancreatic duct and carcinoma of the biliary tract. World J Surg 1986;10:102-10.

10. Tao KS, Lu YG, Wang T, Dou KF. Procedures for congenital choledochal cysts and curative effect analysis in adults. Hepatobiliary Pancreat Dis Int 2002;1:442-5

11. Saing H, Han H, Chan KL, Lam W, Chan FL, Cheng W, et al. Early and late results of excision of choledochal cysts. J Pediatr Surg 1997;32:1563-6.

12. Mihalache F, Tantau M, Diaconu B, Acalovschi M. Survival and quality of life of cholangiocarcinoma patients: a prospective study over a 4 year period. J Gastroenterol Liver Dis 2010;19:285-90.

13. Fan F, Xu DP, Xiong ZX, Li HJ, Xin HB, Zhao H, et al. Clinical significance of intrapancreatic choledochal cyst excision in surgi- cal management of type I choledochal cyst. J Int Med Res 2018;46: 1221-9.

14. Søreide K, Søreide JA. Bile duct cyst as precursor to biliary tract cancer. Ann Surg Oncol 2006;14: 1200-11.
15. Visser BC, Suh I, Way LW, Kang SM. Congenital choledochal cysts in adults. Arch Surg 2004;139: 855-62.

16. Nicholl M, Pitt HA, Wolf P, Cooney J, Kalayoglu M, Shilyansky J, et al. Choledochal cysts in western adults: complexities compared to children. J Gastrointest Surg 2004;8:245-52.

17. Hove A, Meijer VE, Hulcher JBF, Kleine RHJ. Meta-analysis of risk of developing malignancy in congenital choledochal malformation. BJS 2018; 105:482-90. 